\title{
Hazard of sinkhole formation in the Centurion CBD using the Simplified Method of Scenario Supposition
}

\author{
A C Oosthuizen, J L van Rooy
}

A large part of the land south of Pretoria is underlain by dolomite from the Chuniespoort Group of the Transvaal Supergroup. In South Africa, dolomite rock has a notorious reputation for the formation of sinkholes and subsidences. Thousands of people reside and work in the Centurion area, where numerous sinkholes have occurred, causing damage and in some instances loss of property and even lives. Centurion has rapidly densified over the last 40 years, with an increase not only in the number of people, but also in the density of waterborne services. This paper proposes draft guidelines for the allocation of an Inherent Hazard Class for percussion boreholes, referred to as the 'Simplified Method of Scenario Supposition'. This method was then used to classify the Centurion CBD and surrounding area.

\section{INTRODUCTION}

The greater part of land in the area directly south of Pretoria is underlain by dolomite from the Chuniespoort Group of the Transvaal Supergroup. In South Africa dolomite rock has a notorious reputation for the formation of sinkholes and subsidences. Thousands of people reside and work in the Centurion area, where numerous sinkholes have occurred, causing damage and in some instances loss of property and even lives. Standard practice in South Africa is to execute geotechnical investigations on all dolomitic land earmarked for development, irrespective of the type of development.

Dolomite stability reports are submitted to the National Dolomite Databank at the Council for Geoscience (CGS). It is apparent from the available dolomite stability reports submitted over the last 30 years, that hazardous conditions exist in the Central Business District (CBD) area of Centurion, Pretoria. Centurion has rapidly densified over the last 40 years due to its locality between Johannesburg and Pretoria. The Gautrain train route now traverses the Centurion CBD area, and the Centurion Station area around West Street has attracted high-rise developments. This will lead to a further increase in population, with associated increased road traffic and density of people per hectare. The available data, comprising 3587 percussion borehole profiles from 555 dolomite stability reports, could be used to attempt a first-order sinkhole hazard analysis.

The generally accepted current method used to determine the sinkhole hazard is the so-called 'Scenario Supposition Method' (Buttrick et al 2001). This method is incorporated into SANS 1936-2:2012 (SANS 1936), since the principles of this method are currently most commonly being used by practitioners in South Africa.

\section{STUDY AREA}

The Centurion CBD is demarcated by John Vorster Road in the south, Jean Avenue in the north, the N1 highway in the southeast and South Street in the east. The study area includes some of the surrounding suburbs, and is bounded by Trichardt Road in the north, Botha Avenue in the east, the N1 highway in the south and the N14 highway in the west (Figure 1).

The study area covers a surface area of approximately 1657 hectares and is relatively flat-lying, sloping gently towards the Hennops River which cuts through the centre of the CBD. The majority of the $\mathrm{CBD}$ and surrounding areas is developed, with commercial developments around the Centurion Lake and residential development in the surrounding areas (Figure 1).

\section{GEOLOGY OF THE \\ CENTURION CBD AREA}

Most of the CBD area is underlain by chert and dolomite rocks of the Monte Christo Formation, with the Lyttelton Formation present along the eastern boundary of the study area, and the Oaktree Formation occupying a small area in the southern corner. Dolomite from the Lyttelton and
TECHNICAL PAPER

\section{JOURNAL OF THE SOUTH AFRICAN INSTITUTION OF CIVIL ENGINEERING}

Vol 57 No 2, June 2015, Pages 69-75, Paper 1061

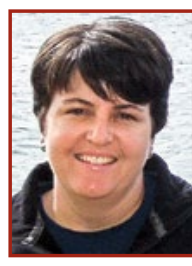

THARINA OOSTHUIZEN (Pr Sci Nat, MSAIEG) completed BSC (Hons) and MSc degrees in Engineering and Environmental Geology at the University of Pretoria in 2003 and 2013 respectively. She started her career in the mining environment where she was involved in highwall stability monitoring and exploration until late 2005, when she joined the Council for Geoscience, initially doing some work on foundation investigations for dams. She currently oversees the Council's dolomite peer reviews, and is doing research in the field of dolomite.

Contact details:

Private Bag X112

Pretoria

0001

T: $+27(0) 128411160$

E: toosthuizen@geoscience.org.za

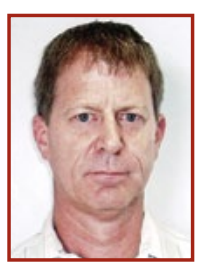

PROF LOUIS VAN ROOY (Pr Sci Nat., MSAIEG) started lecturing in the Department of Geology at the University of Pretoria in 1985, and obtained his PhD degree in Engineering Geology in 1992. He lectures to pre-and postgraduate mining and civil engineering, hydrogeology and engineering geology students. His research interests include durability of basic igneous rocks for use in civil engineering construction, problem soils, safe development on dolomite land, and rock engineering. He has supervised or co-supervised more than $25 \mathrm{MSc}$ and PhD students, and is author or co-author of more than 30 papers in journals and conferences proceedings. He serves on the councils of both the SAIEG (South African Institute of Engineering and Environmental Geologists) and IAEG (International Association for Engineering Geology and the Environment), and is the Vice President for Africa IAEG.

Contact details:

Department of Geology

University of Pretoria

Private Bag X20

Hatfield

0028

T: $+27(0) 124202023$

E:louis.vanrooy@up.ac.za 


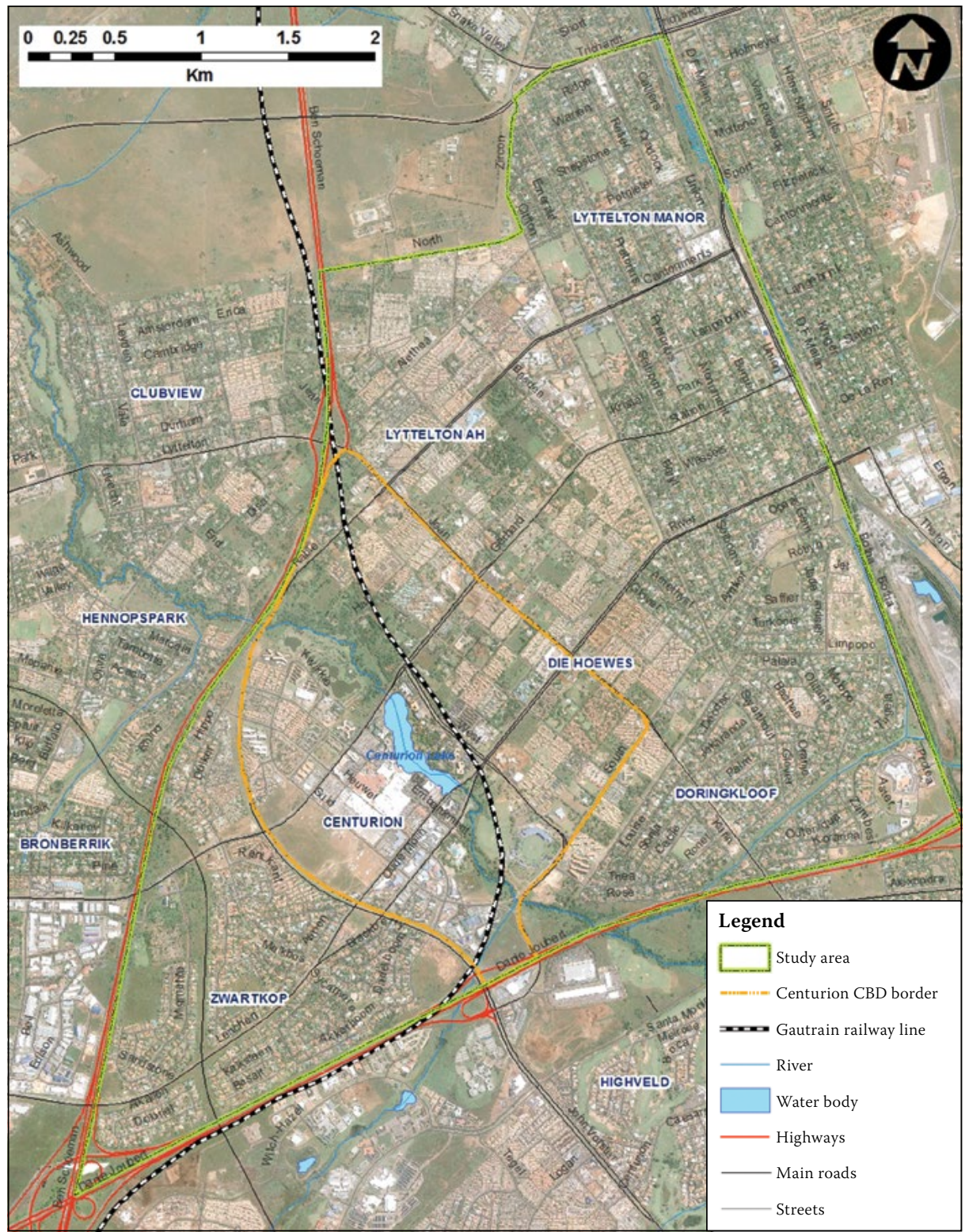

Figure 1 Location of the study area

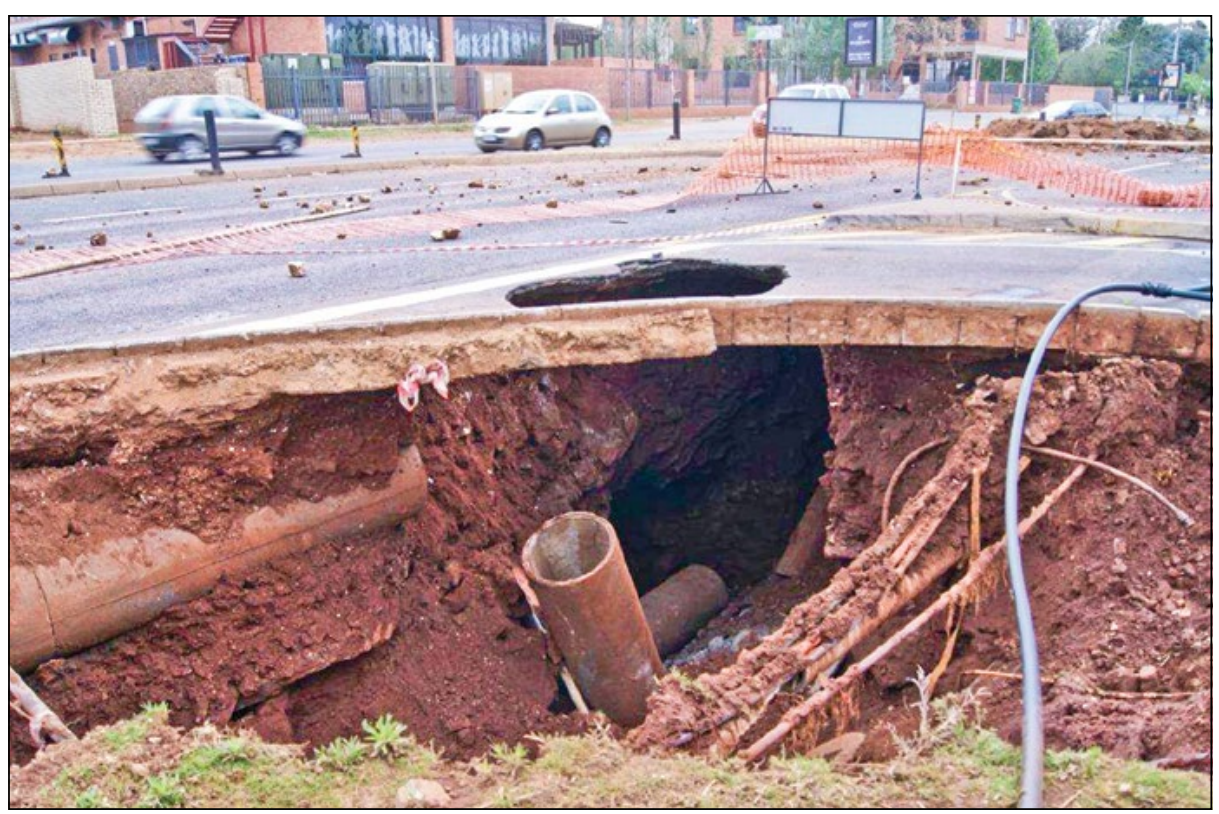

Photo 1 A sinkhole that occurred in Jean Avenue (2012), costing millions of rand to repair

Oaktree Formations are generally chertpoor compared to the chert-rich Monte Christo Formation.
Syenite intrusions in the form of sills and dykes are present in the dolomite bedrock, and a specific large syenite sill is present towards the southern boundary of the Centurion CBD area in Zwartkop. A prominent north-south trending dyke is present along the eastern boundary of the CBD, with a smaller northwest-southeast trending dyke in the Lyttelton Agricultural Holdings. Alluvial deposits occur in the Hennops River floodplain and a small Karoo outlier (Vryheid Formation) is present on the northwestern boundary.

\section{GEOHYDROLOGY}

The Centurion CBD area is situated in the Irene catchment which comprises four sub-catchments, or compartments which are hydraulically connected, as evidenced by the direction of groundwater flow (Hobbs 1988). The four sub-catchments are analogous to the Fountains West, Fountains East, Doornkloof West and Doornkloof East compartments described by Vegter (1986).

Most of the CBD area is situated in the Fountains West groundwater compartment. Hobbs (1988) indicates that an extremely weak groundwater gradient of some $0.2 \%$ is manifested from immediately north of the Hennops River in a north-north-easterly direction towards the Fountains West spring, indicating a high transmissivity of the dolomite aquifer in this sub-catchment. According to a groundwater level contour map by Hobbs, the groundwater level of the Fountains West groundwater compartment in this area ranges from 1416 mamsl in the south to 1385 mamsl in the north. This constitutes a range of $48 \mathrm{~m}$ below ground surface in the south to $91 \mathrm{~m}$ below ground surface in the north.

The Fountains East groundwater compartment is present along the eastern boundary of the CBD area. This compartment drains in a north-westerly direction to the East Fountain Spring in the north (Hobbs 1988). According to Hobbs, the groundwater level of the Fountains East groundwater compartment in this area ranges from 1429 mamsl in the south to 1425 mamsl in the north, indicating a relatively flat groundwater level across this compartment. The groundwater level of the CBD area therefore ranges between $16 \mathrm{~m}$ below ground surface in the south to $20 \mathrm{~m}$ below ground surface in the north.

Recent groundwater studies for specifically the Gautrain Rapid Rail and other developments in the Centurion area revealed that groundwater abstraction (mainly by the municipality) does not have an influence on the aquifer, as the Irene catchment is in a relatively undisturbed condition (Ove Arup 2009). Some localised 


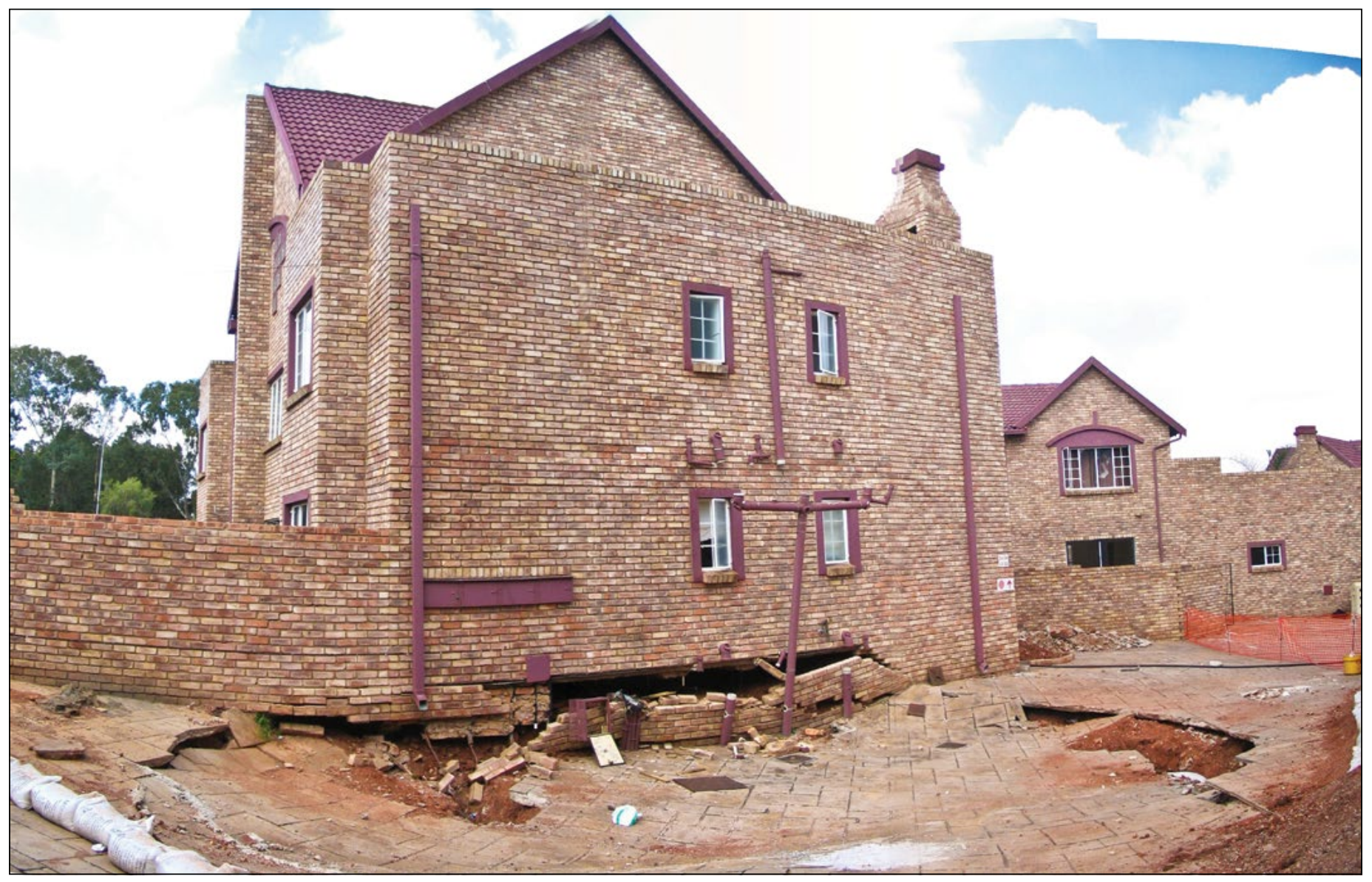

Photo $2 \mathrm{~A}$ sinkhole that occurred in a residential complex, which led to the demolition of two units

lowering of the groundwater level has been observed in the area of the Kentron borehole where water is abstracted by the municipality, but this borehole is situated in the Doornkloof West groundwater compartment, which does not form part of the study area. Groundwater monitoring borehole A2N0528, situated towards the west of the CBD area, also shows a relatively stable groundwater level (with seasonal fluctuations) between 1985 and 2009, although the groundwater has risen three to four metres during 1995 and 1996. The Centurion CBD area is therefore considered to not be affected by dewatering.

\section{SINKHOLE DATABASE}

A total of 119 sinkholes have been recorded in the Centurion CBD area since the early 1970s until mid-2012, and their positions are indicated on Figure 2 (page 74). The sinkhole records are under review and many of the events lack detailed information. Most of the records in the database were captured by CGS staff, while some information was also obtained from the City of Tshwane. At present, this database is not available to the public, mainly due to the sensitivity of this information and the effect that it might have on property value.

\section{Table 1 Number of sinkholes that have occurred in each stratigraphic formation}

\begin{tabular}{|l|c|c|}
\hline \multicolumn{1}{|c|}{ Geological succession / formation } & Area (ha) & $\begin{array}{c}\text { No of sinkholes } \\
\text { occurred }\end{array}$ \\
\hline Lyttelton Formation & 91.82 & 8 \\
\hline Monte Christo Formation & 1246.61 & 03 \\
\hline Oaktree Formation & 44.80 & 0 \\
\hline Chert Breccia & 9.77 & 1 \\
\hline Dolerite & 35.10 & 5 \\
\hline Quartz-diorite (syenite intrusions) & 171.34 & 2 \\
\hline Alluvium & 58.31 & 5 \\
\hline
\end{tabular}

\section{Consequence of sinkhole occurrence}

The occurrence of sinkholes has led to the demolition of seven houses and other structures, with loss of money to landowners, while three lives were also lost. The loss of life happened during the rehabilitation of a sinkhole.

Photographs 1 and 2 present some examples of sinkholes in the Centurion CBD area.

\section{Nature of sinkhole occurrences}

The following conclusions could be drawn from the CGS sinkhole database:

- The surface extent of the largest reported sinkhole is $32 \mathrm{~m} \times 23 \mathrm{~m}$ and occurred in Lyttelton as a result of a broken water pipe.

- The deepest reported sinkhole is $10 \mathrm{~m}$ and was caused by a leaking sewerage pipe.

- Only one sinkhole occurred on syenite close to the John Vorster and Jean Avenue intersection (detailed information on this event is lacking).

- A total of 110 sinkholes (92\% of database) occurred in the Monte Christo Formation and only 8 (7\%) in the Lyttelton Formation. No sinkholes were recorded in the Oaktree Formation (Table 1).

- Ninety records (75.6\%) of the database have information regarding the type of event, with most of the events listed as 


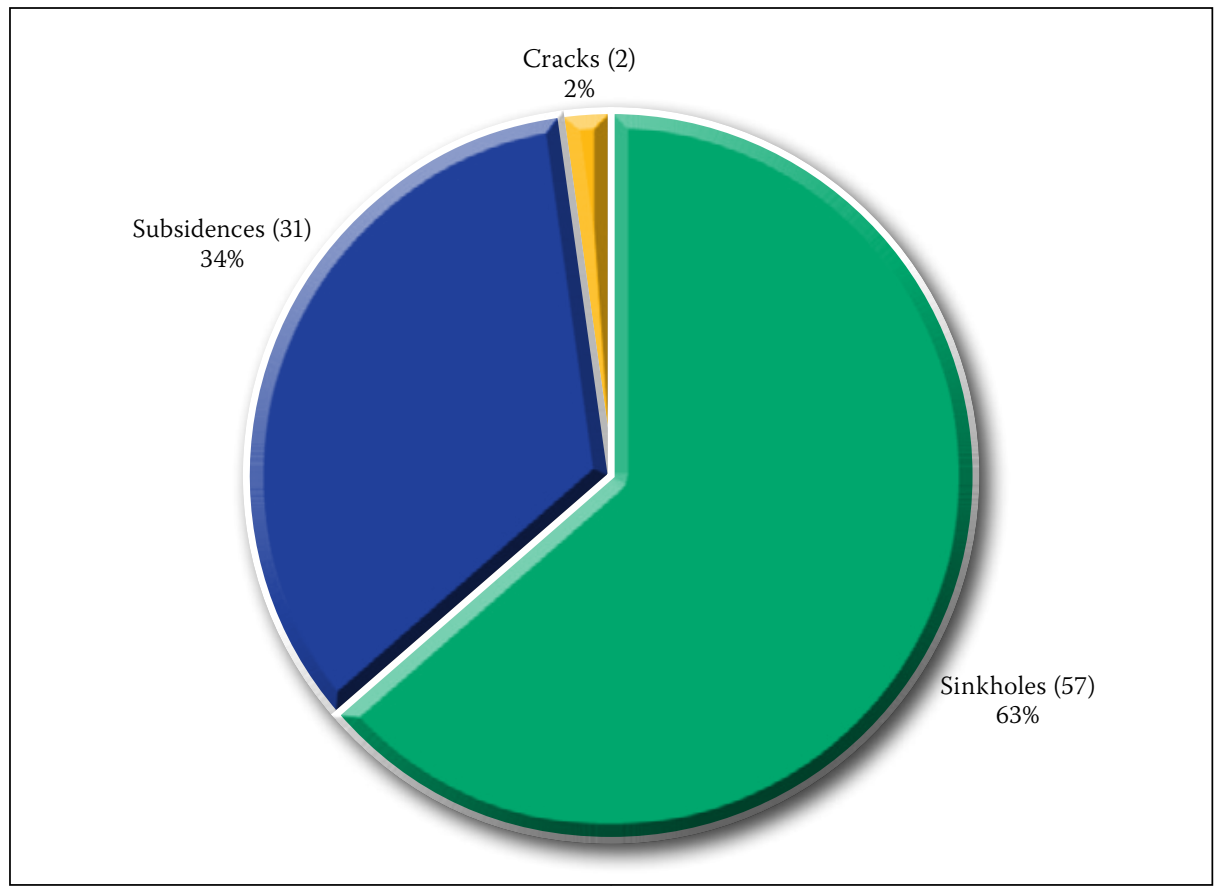

Graph 1 Distribution of type of sinkhole events

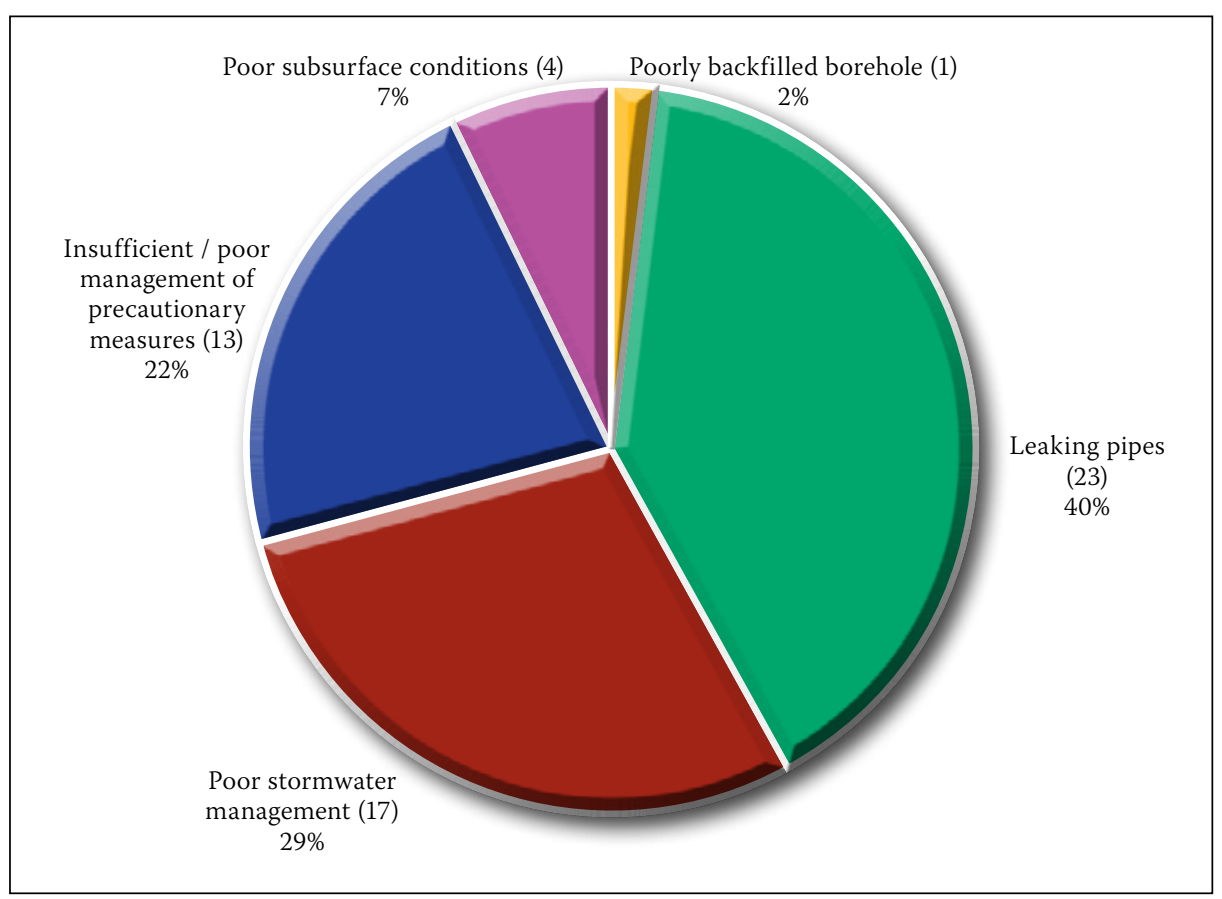

Graph 2 Distribution of cause of sinkhole events

\section{Table 2 Suggested scale of sinkhole sizes (Buttrick et al 2001)}

\begin{tabular}{|l|c|c|}
\hline \multicolumn{1}{|c|}{$\begin{array}{c}\text { Maximum potential } \\
\text { development space }\end{array}$} & $\begin{array}{c}\text { Maximum diameter of } \\
\text { surface manifestation } \\
\text { (dimension: metres) }\end{array}$ & $\begin{array}{c}\text { Suggested } \\
\text { terminology }\end{array}$ \\
\hline Small potential development space & $<2$ & Small sinkhole \\
\hline Medium potential development space & $2-5$ & Large sinkhole \\
\hline Large potential development space & $5-15$ & Very large sinkhole \\
\hline Very large potential development space & $>15$ & \\
\hline
\end{tabular}

sinkholes. Graph 1 indicates the distribution of type of instability events.

- The average sinkhole depth is $3.24 \mathrm{~m}$ (data from 47 sinkholes).

- The average sinkhole diameter is $5.1 \mathrm{~m}$ (data from 53 sinkholes).
Table 3 Guidelines for determining the Inherent Hazard Class in a non-dewatering scenario, as applied in the Centurion CBD and surrounds

\begin{tabular}{|c|c|}
\hline $\begin{array}{c}\text { Inherent } \\
\text { Hazard } \\
\text { Class }\end{array}$ & $\begin{array}{c}\text { Characteristics } \\
\text { (non-dewatering scenario) }\end{array}$ \\
\hline IHC 1 & $\begin{array}{l}\text { Overburden must consist of a } \\
\text { competent, non-dolomitic cover } \\
\text { (e.g. shale or syenite) of at least } \\
30 \mathrm{~m} \text { in thickness, overlying } \\
\text { dolomite or chert residuum. } \\
\text { No voids (cavities) or low-density } \\
\text { material (wad) must be present. }\end{array}$ \\
\hline IHC 2 & $\begin{array}{l}\text { Overburden must consist of a } \\
\text { competent, non-dolomitic cover } \\
\text { (e.g. shale or syenite) of at least } \\
20 \mathrm{~m} \text { in thickness, overlying } \\
\text { dolomite or chert residuum. } \\
\text { No voids (cavities) or low-density } \\
\text { material (wad) must be present. } \\
\quad \text { OR } \\
\text { A very shallow, static groundwater } \\
\text { level exists, i.e. less than } 5 \text { m from } \\
\text { surface, which forms a solid base. }\end{array}$ \\
\hline IHC 3 & $\begin{array}{l}\text { Dolomite bedrock is situated } \\
\text { between a depth of } 6 \mathrm{~m} \text { and } 15 \mathrm{~m} \\
\text { below surface. } \\
\text { No voids (cavities) must be } \\
\text { present. } \\
\text { If low-density material (wad) is } \\
\text { present, no more than } 2 \mathrm{~m} \text { should } \\
\text { have recorded penetration rates of } \\
\text { less than } 15 \text { seconds. }\end{array}$ \\
\hline IHC 4 & $\begin{array}{l}\text { Dolomite bedrock is situated } \\
\text { deeper than } 15 \mathrm{~m} \text { in depth. } \\
\text { No voids (cavities) must be } \\
\text { present. } \\
\text { If low-density material is present, } \\
\text { no more than } 2 \mathrm{~m} \text { should have } \\
\text { recorded penetration rates of less } \\
\text { than } 15 \text { seconds. }\end{array}$ \\
\hline IHC 5 & $\begin{array}{l}\text { Dolomite bedrock is shallower or } \\
\text { situated at } 5 \mathrm{~m} \text { in depth. } \\
\text { Dolomite bedrock is } \\
\text { discontinuous, i.e. pinnacles and } \\
\text { grykes are believed to exist, the } \\
\text { latter acting as conduits to the } \\
\text { voids below. } \\
\text { It is assumed that the grykes } \\
\text { are narrow (i.e. }<1 \mathrm{~m} \text { ) and are } \\
\text { present in the bedrock at depths } \\
\text { exceeding } 5 \mathrm{~m} \text {. } \\
\text { No voids (cavities) are present in } \\
\text { the dolomite bedrock. }\end{array}$ \\
\hline IHC 6 & $\begin{array}{l}\text { Dolomite bedrock is situated } \\
\text { between } 6 \mathrm{~m} \text { and a maximum of } \\
20 \mathrm{~m} \text { in depth. } \\
\text { Voids and/or low-density material } \\
\text { (wad) are present. The low-density } \\
\text { material has recorded penetration } \\
\text { rates of less than } 15 \text { seconds and is } \\
\text { more than } 2 \mathrm{~m} \text { in thickness. }\end{array}$ \\
\hline IHC 7 & $\begin{array}{l}\text { Dolomite bedrock is situated } \\
\text { between } 20 \mathrm{~m} \text { and a maximum of } \\
35 \mathrm{~m} \text { in depth. } \\
\text { Voids and/or low-density material } \\
\text { (wad) are present. The low-density } \\
\text { material has recorded penetration } \\
\text { rates of less than } 15 \text { seconds and is } \\
\text { more than } 2 \mathrm{~m} \text { in thickness. }\end{array}$ \\
\hline IHC 8 & $\begin{array}{l}\text { Dolomite bedrock is situated } \\
\text { deeper than } 35 \mathrm{~m} \text { in depth. } \\
\text { Voids and/or low-density material } \\
\text { (wad) are present. The low-density } \\
\text { material has recorded penetration } \\
\text { rates of less than } 15 \text { seconds and is } \\
\text { more than } 5 \mathrm{~m} \text { in thickness. }\end{array}$ \\
\hline
\end{tabular}


There is no obligation to report these instability events and the records are therefore not always complete. Only 58 of the sinkhole records (49\%) have information regarding the possible causes (Graph 2). Although limited, the information shows that $93 \%$ of the events in the Centurion CBD occurred as a result of human disturbance of the natural ground conditions, confirming deductions by Buttrick et al (2001).

\section{Sinkhole size distribution}

Buttrick and Van Schalkwyk (1995) proposed a scale of sinkhole sizes based on the potential development space that was slightly amended by Buttrick et al (2001), and is widely used to refer to a specific sinkhole size (Table 2).

Graph 3 shows the size distribution of the sinkholes based on Table 2, with just fewer than half of the sinkholes (49.1\%) falling into the medium-sized sinkhole range ( $2 \mathrm{~m}$ to $5 \mathrm{~m}$ diameter).

The sinkhole size distribution (Graph 4) indicates that almost $10 \%$ of all sinkholes were smaller than $1 \mathrm{~m}$ in diameter. Almost a third (28.3\%) are between $2 \mathrm{~m}$ and $3 \mathrm{~m}$, followed by $13.2 \%$ between $3 \mathrm{~m}$ and $4 \mathrm{~m}$ in diameter. Only $17 \%$ of all sinkholes were larger than $10 \mathrm{~m}$, whereas the remaining (83\%) sinkholes are less than $9 \mathrm{~m}$ in diameter. Graph 4 confirms that medium-sized sinkholes $(2 \mathrm{~m}-5 \mathrm{~m})$ dominate in the Centurion CBD area.

It should be noted that these graphs only represent the available information (45\% of records).

According to the information in the available sinkhole database, $40 \%$ sinkholes or subsidences formed as a result of leaking water-bearing services, $29 \%$ as a result of poor surface/stormwater management and $22 \%$ as a result of inadequate or poor

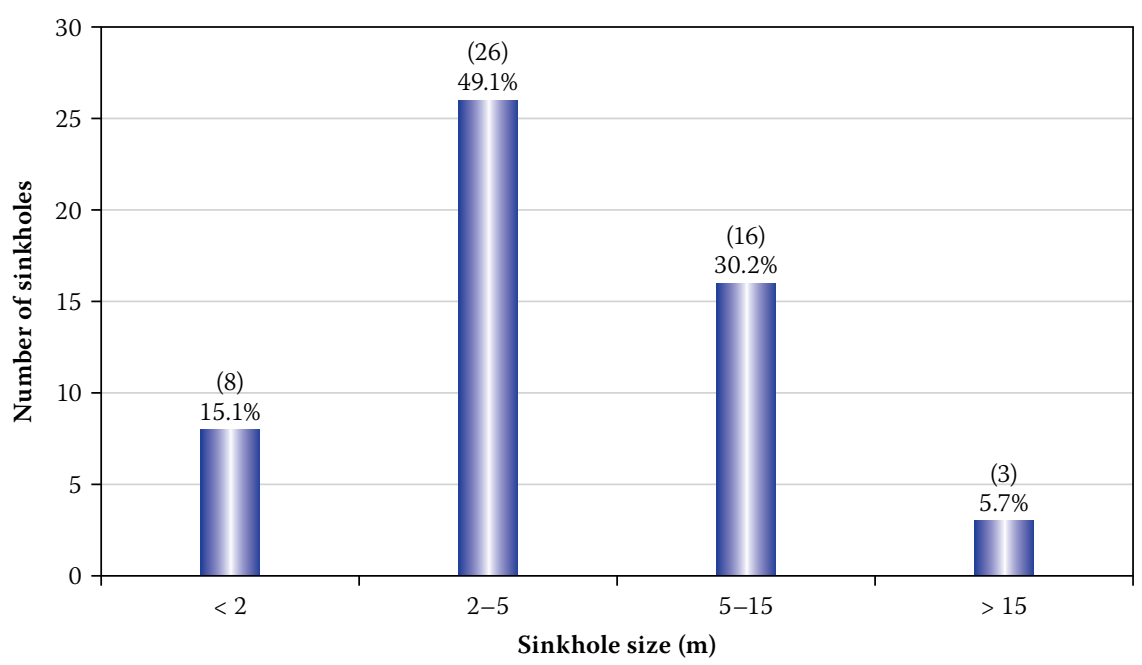

Graph 3 The sinkhole size distribution, based on the suggested scale of sinkhole sizes (Buttrick et al 2001)

precautionary measures. Only one sinkhole (2\%) occurred as a result of a poorly backfilled borehole, whereas $7 \%$ occurred as a result of poor subsurface conditions. Using limited information ( $49 \%$ of the database has information relating to the cause thereof) it is evident that $93 \%$ of the events in the Centurion CBD area occurred as a result of man's disturbance of the natural ground conditions.

\section{CLASSIFICATION IN TERMS OF THE HAZARD OF SINKHOLE FORMATION}

Since there are no numerical limits to the Scenario Supposition method, draft guidelines for allocation of each hazard class, based on CGS institutional memory and experience, have been developed. This approach is mainly based on the dolomite bedrock depth and the mobilisation potential of the overlying horizons. The size of sinkhole that could develop is again a function of the depth to dolomite bedrock, i.e. the thinner the overburden the smaller size sinkhole is expected and vice versa.

Determination of the sinkhole hazard follows a process where an Inherent Hazard Class is assigned to each geotechnical investigation borehole, depending on the characteristics of the material encountered in that borehole. The basic guidelines are provided in Table 3, specifically for the Centurion $\mathrm{CBD}$ and the non-dewatering condition, since dewatering has had no influence on stability in Centurion.

This hazard determination is merely based on the assumption that a larger size sinkhole will develop in deeper dolomite bedrock environments. This method is based on experience and the understanding of dolomite stability conditions through using the Method of Scenario Supposition (Buttrick et al 2001), but it provides a simplified version of the eight Inherent Hazard Classes; therefore it is proposed as the Simplified Method of Scenario Supposition.

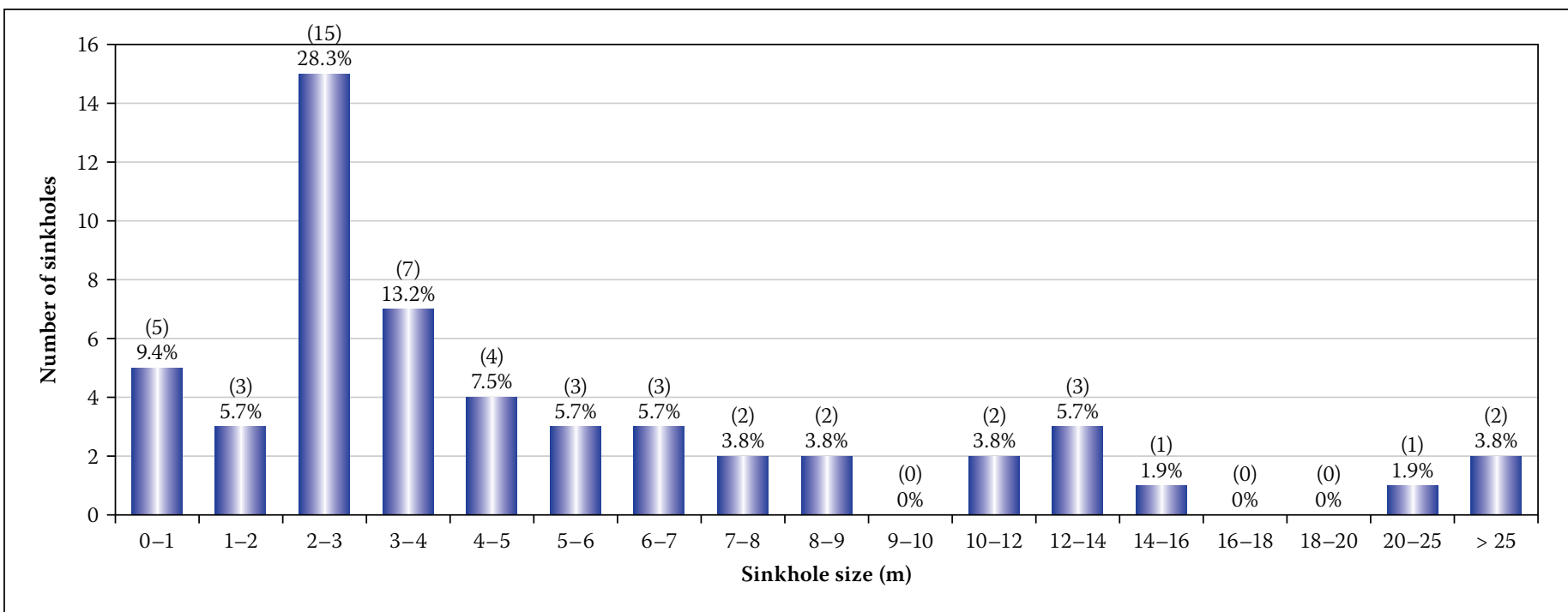




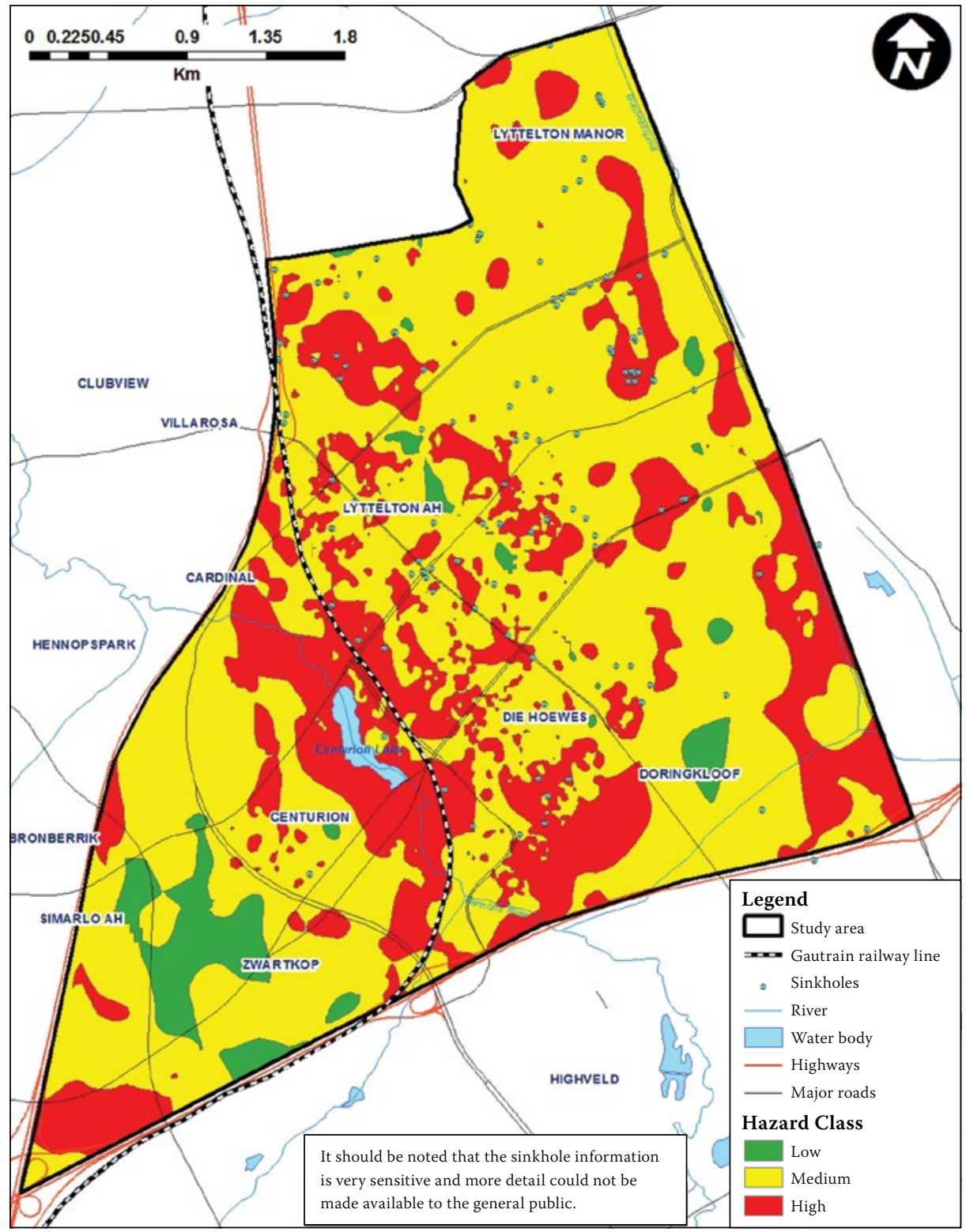

Figure 2 Inherent Hazard Map of the Centurion CBD area showing the sinkhole occurrences

Table 4 Percentages of each Inherent Hazard Class in the Centurion CBD area

\begin{tabular}{|c|c|c|c|c|}
\hline IHC & Total no of boreholes & Boreholes as percentage & & \\
\hline 1 & 84 & $2.34 \%$ & \multirow{2}{*}{ Low } & \multirow{2}{*}{$10.51 \%$} \\
\hline 2 & 293 & $8.17 \%$ & & \\
\hline 3 & 953 & $26.57 \%$ & \multirow{2}{*}{ Medium } & \multirow{2}{*}{$50.46 \%$} \\
\hline 4 & 857 & $23.89 \%$ & & \\
\hline 5 & 672 & $18.73 \%$ & \multirow{4}{*}{ High } & \multirow{4}{*}{$39.03 \%$} \\
\hline 6 & 296 & $8.25 \%$ & & \\
\hline 7 & 330 & $9.20 \%$ & & \\
\hline 8 & 102 & $2.84 \%$ & & \\
\hline
\end{tabular}

Table 4 indicates the distribution of the Inherent Hazard Classes in the Centurion CBD area, with most of the boreholes (953) falling into IHC 3 , followed by IHC 4 (857) and IHC 5 (672).

The Spatial Analyst extension of ArcMap was used to create an Inherent Hazard Classification Map in terms of the low, medium and high classification (Figure 2).
The map indicates that high-hazard conditions prevail in the areas surrounding the Centurion Lake, and are also present along the south-eastern boundary of the Centurion CBD area along Botha Avenue. Isolated areas of high-hazard conditions are also scattered across the centre of the Centurion CBD area, and scattered small areas of low hazard are present, mainly in Zwartkop and Doringkloof.
Table 5 Coverage of each hazard class in the Centurion CBD area, from Figure 2

\begin{tabular}{|l|c|c|}
\hline $\begin{array}{c}\text { Inherent } \\
\text { Hazard Class }\end{array}$ & $\begin{array}{c}\text { Surface area } \\
\text { (hectares) }\end{array}$ & $\begin{array}{c}\text { Percentage cover } \\
\text { in Centurion } \\
\text { CBD area }\end{array}$ \\
\hline Low & 73 & $4.4 \%$ \\
\hline Medium & 1111 & $67 \%$ \\
\hline High & 473 & $28.6 \%$ \\
\hline
\end{tabular}

Table 6 Number of sinkholes that have occurred in each of the hazard classes

\begin{tabular}{|l|c|c|}
\hline $\begin{array}{c}\text { Inherent } \\
\text { Hazard Class }\end{array}$ & $\begin{array}{c}\text { No of } \\
\text { sinkholes }\end{array}$ & $\begin{array}{c}\text { Sinkholes as } \\
\text { percentage }\end{array}$ \\
\hline Low & 0 & $0 \%$ \\
\hline Medium & 83 & $69.7 \%$ \\
\hline High & 36 & $30.3 \%$ \\
\hline
\end{tabular}

This map has been used to calculate the coverage and surface area of each of the Inherent Hazard Classes, and the respective percentages are given in Table 5 .

It is evident that two thirds of the Centurion CBD area represents a medium Inherent Hazard for sinkhole formation, and almost a third can be considered as having a high Inherent Hazard for the formation of sinkholes, with only a small portion of the area (4.4\%) representing low-hazard conditions.

\section{Comparison between the CBD} hazard map and sinkhole occurrence The 119 sinkholes that occurred in the Centurion CBD area were plotted to compare the occurrence of sinkholes against the low-, medium- and high-hazard areas (Figure 2). Table 6 shows the number of sinkholes in each of the hazard areas.

The comparison between the hazard map and the previous occurrence of sinkholes generally does not correlate well. The map does show that no sinkholes occurred in the areas classified as having a low hazard for sinkhole formation, which suggests that the delineation of low-hazard areas was accurate and that the classification system defines these areas well. Surprisingly, a vast majority (69.7\%) of the sinkholes in the Centurion CBD area occurred in areas classified as having a medium hazard for the formation of sinkholes. It should, however, also be borne in mind that $67 \%$ of the area was classified as having a medium hazard for sinkhole formation.

Another influencing factor to consider is that the high-hazard areas are generally not developed, whereas the medium-hazard areas are densely developed, therefore more wet services are present in these areas, resulting in a higher number of sinkholes. The position, volume, type and age of wet 
services also contribute to the type, size and time of sinkhole formation, but this was not studied in detail in this paper.

\section{CONCLUSIONS}

1. The greater part of land in the area directly south of Pretoria is underlain by dolomite from the Chuniespoort Group of the Transvaal Supergroup. In South Africa dolomite rock has a notorious reputation for the formation of sinkholes and subsidences. Thousands of people reside and work in the Centurion area, where numerous sinkholes have occurred.

2. From the available dolomite stability reports submitted to the Council for Geoscience over the last 30 years it became evident that hazardous conditions exist in the CBD area of Centurion, Pretoria. This first-order sinkhole hazard analysis incorporates the borehole information (3 587 percussion borehole profiles) extracted from 555 dolomite stability reports.

3. The area covers a surface of approximately 1657 hectares where a total of 119 sinkholes have occurred up to mid-2012. This constitutes one sinkhole per 13.9 hectares or 7.2 sinkholes per square kilometre.

4. It is evident that $93 \%$ of the instability events in the Centurion CBD area occurred as a result of man's disturbance of the natural ground conditions.

5. Medium-sized sinkholes prevail in this area, with just less than half of the sinkholes (49.1\%) being considered as medium-sized. The database showed that $30.2 \%$ were classified as large-sized sinkholes, while small-sized sinkholes constituted $15.1 \%$ of the events, with only $5.7 \%$ being more than $15 \mathrm{~m}$ in diameter, i.e. very large sinkholes.

6. Draft guidelines for allocation of an Inherent Hazard Class have been developed. This approach is mainly based on the dolomite bedrock depth and the mobilisation potential of the overlying horizons. The size of sinkhole that could develop is again a function of the depth to dolomite bedrock, i.e. the thinner the overburden the smaller size sinkhole is expected and vice versa. The sinkhole size is not calculated by using the angle of draw as proposed in the Method of Scenario Supposition (Buttrick et al 2001), although most of the other factors are considered in this methodology, which is based on the same principles of the Method of Scenario Supposition. This approach simplifies the Method of Scenario Supposition, and it is therefore proposed as the 'Simplified Method of Scenario Supposition'.
7. A hazard map of the Centurion CBD area, using the Simplified Method of Scenario Supposition with the Spatial Analyst ${ }^{\circ}$ extension of ArcGIS ${ }^{\circ}$, was created. This map generally indicates a medium to high susceptibility to sinkhole formation, with pockets of low-hazard areas. The following conclusions could be made from the hazard classification of the Centurion CBD and surrounding areas:

- The conditions are not as poor as had always been perceived.

- The largest area of high-hazard conditions is present in the area immediately north and east of the Hennops River and Centurion Lake.

- The largest area of low-hazard conditions is present in the area of Zwartkop.

- The Centurion CBD area is mostly represented by medium-hazard conditions (Inherent Hazard Classes 3 and 4), which constitute $50.5 \%$ of the boreholes in the area.

- Only $2.3 \%$ of the boreholes in the Centurion CBD area were classified as Inherent Hazard Class 1, whereas $2.8 \%$ of the boreholes were classified as Inherent Hazard Class 8.

- Almost two thirds of the Centurion CBD area represents a medium hazard for sinkhole formation, with almost a third of the area considered as having a high hazard for the formation of sinkholes, and only a small portion of the area $(5 \%)$ representing low-hazard conditions.

8. Upon comparison of the hazard map and the previous occurrence of sinkholes, it became evident that the vast majority (70\%) of the sinkholes occurred in the areas classified as having a medium hazard for sinkhole formation. Two thirds of the study area is classified as having a medium hazard for sinkhole formation, which is where most of the wet services are present. Leaking wet services have directly caused $40 \%$ of the sinkholes in this area, as revealed from available information.

9. Additional research has been conducted, based on the outcomes of this study, which will be presented in the near future.

\section{REFERENCES}

Buttrick, D B \& Van Schalkwyk, A 1995. The method of Scenario Supposition for stability evaluation of sites on dolomitic land in South Africa. Journal of the South African Institution of Civil Engineering, 37: 9-14.

Buttrick, D B, Van Schalkwyk, A, Kleywegt, R J \& Watermeyer, R 2001. Proposed method for dolomite land hazard and risk assessment in South Africa.
Journal of the South African Institution of Civil Engineering, 43(2): 27-36.

Hobbs, P J 1988. Hydrogeology of the Verwoerdburg dolomite aquifer. Technical Report GH3502. Pretoria: Department of Water Affairs.

Ove Arup \& Partners Ltd 2009. Gautrain Rapid Rail Link - Hydrogeological impact study. Report/08, Issue 1. 24.

SANS (South African National Standard) 2012. SANS 1936-2:2012, Edition 1. Development of Dolomite Land. Part 2: Geotechnical Investigations and Determinations. Pretoria: SABS Standards Division.

Vegter, J R 1986. Emergency groundwater supplies from dolomite strata in the PWV area: Overview and status of investigations. November 1983 December 1985. Technical Report GH3435. Pretoria: Department of Water Affairs.

\section{BIBLIOGRAPHY}

AGES Consulting 2012. Zwartkop Golf Estate: Groundwater level stability investigation. Clubview 92 Extension geohydrological assessment for water level stability. Report No AS-R-2012-05-18.

Buttrick, D B 1992. Characterisation and appropriate development of sites on dolomite. PhD Thesis, Pretoria: University of Pretoria.

Buttrick, D B \& Van Schalkwyk, A 1998. Hazard and risk assessment for sinkhole formation on dolomite land in South Africa. Environmental Geology, 36(12): 170-178.

Button, A 1973. The stratigraphic history of the Malmani dolomite in the eastern and northeastern Transvaal. Transactions of the Geological Society of South Africa, 76: 229-247.

Honniball, H P 1999. The relationship between surface features and subsidences in the dolomitic area south of Pretoria. MEng Dissertation, Pretoria: University of Pretoria.

Johnson, M R, Anhaeusser, C R \& Thomas, R J (Eds) 2006. The Geology of South Africa. The Geological Society of South Africa, Johannesburg, and the Council for Geoscience, Pretoria.

Relly, B H 1976. Geological report on the stability of the Lyttelton agricultural holdings - A general study of a dolomite area. Report No F2376, CGS Dolomite Databank.

Sartain, N, Mian, J, O'Riordan, N \& Storry, R 2011. Case study on the assessment of sinkhole risk for the development of infrastructure of karstic ground. Proceedings, Third International Symposium on Geotechnical Safety and Risk, Munich, Germany, 2-3 June, pp 635-642.

Schöning, W L 1996. Distribution of sinkholes and dolines in the area south of Pretoria. Proceedings, Geotechnical Division of SAICE's Seminar on the Development of Dolomitic Land, Pretoria, pp 7/1-7/11.

Watermeyer, R B, Buttrick D B, Trollip, N Y G, Gerber, A A \& Pieterse, N 2008. A performance-based approach to the development of dolomite land. Proceedings, Geotechnical Division of SAICE's Conference on Problem Soils in South Africa, 3-4 November, Midrand, pp 167-174. 